\title{
ECONOMICAL ASSESSMENT OF AN INVESTMENT RELATED TO THE ESTABLISHMENT OF A NEW FARROWING PLACE AND PIG-REARING BUILDING
}

\author{
BrigitTa Zsótér, ÁGNes Milojev \\ University of Szeged Faculty of Engineering \\ Department of Economics and Rural Development \\ Mars ter 7. 6724 Szeged, Hungary \\ zsoterb@mk.u-szeged.hu
}

\begin{abstract}
In our research work we aimed at carrying out an economical assessment of an investment and development of substantial volume. The examined project was completed at a pig-farm during which a new farrowing place and pig rearing building were built, as well as the renovation of the existing pig-farm. All of them were financed partly from the firm's own source, partly from a non-repayable aid granted by the state, and finally from a credit granted by a commercial bank. The term of the credit is 10 years and the return of the investment expected by the investors is $8 \%$, so we carried out our calculations according to these data. We examined the three possible ways of financing the investment from the economical point of view, as a result we proposed three hypotheses. Our hypotheses are: Hypothesis 1 (Case „A”): The investment will be financially recovered within the examined period of 10 years if it is financed from the firm's own source, the state grant and the bank credit. Hypothesis 2 (Case „B”): The investment can be economically completed within the given period of time if the project meets the costs from the firm's own source and the credit. Hypothesis 3 (Case „C”): The investment will be economically accomplished within the examined 10 years provided the firm finances the project from their own source and the state grant. In our calculations we used the net present value (NPV), the internal rate of return (IRR), the payback time (PB), the discounted payback time (DPB) and the profitability index (PI) as economy indicators. We carried out our calculations regarding 10 years to be able to compare the results since the term of the granted credit is 10 years, too.
\end{abstract}

Keywords: payback time, discounted payback time, net present value, internal rate of return, profitability index

\section{INTRODUCTION}

Pig-breeding is a significant branch of animal husbandry all over the world as it has had an important part in supplying people with food for thousands of years (HORVÁTH AND KOMAREK, 2016). In 2013 the global pig production exceeded the 114 million tons, while the global pig population the 1 billion entities. Presumably, the world's pork production will have approximated the 130 million tons by 2023 . The global pork consumption is estimated to increase to the approximate amount of 470 million tons by 2050 (NOVOTNINÉ DANKÓ, 2015). The pork branch has undergone serious changes in the latest periods (BALOGH ET AL., 2013). The market conditions (KÖTELES ET AL., 2017), the consumer habits and needs have altered, also optimization of production costs and efficiency has become a crucial factor (FEHÉR AND SZAKÁLY, 2017). The strict European and regional directives set limits in the fields of health care, ammonia emission, manure management and animal welfare, which make the pig-breeders' situation even more difficult (BRABANT ET AL., 2012). However, the great reproduction capacity of pigs, the good adaptability of theirs and their efficient pork production capacity are all employed in several parts of the world (POPP ET AL., 2013). It is typical to the pig-breeding branch that the investments return relatively fast, they mean a continuous source of income for the firms (BABINSZKY ET AL., 2000). 
The gross amount of money needed for the examined investment was 603,000,000 HUF (1,932,011.15 EUR), of which the firm financed 190,000,000 HUF (608,759.732 EUR) from their own resources. The joint stock company gained from a tender 240.000.000 HUF $(768,959.662$ EUR) in form of a non-repayable aid granted by the state which helped the successful realization of the project. Besides, the company took a loan of $170,000,000 \mathrm{Ft}$ $(544,679.76$ EUR) from a commercial bank. The examined project was completed at a pigfarm during which a new farrowing place and pig rearing building were built, as well as the renovation of the existing pig-farm was accomplished. The contractors put a great emphasis on realization of the necessary new technology, so they built new roads on the site and a straw-fed boiler was constructed to increase the efficiency of heating in the pig farm, the farrowing place and the pig rearing building. Besides that, a modern ventilation, cooling, fodder transporting, distributing and watering system and a drug delivery panel were installed. The buildings were supplied with slatted floors which made the construction of an efficient fertilizer drainage system, the so-called lagoon-typed drainage system, possible. We should not ignore food safety (FABULYA ET AL., 2015), the logistics of food safety and quality (GÁL, 2008) and the product, the result of production management (IRIMIE ET AL., 2014).

\section{MATERIAL AND METHOD}

We consider investment the group of activities which begin at procuring the devices and finish with the installation, so using the devices in the proper way. While by renovation we mean any activity aimed at restoring the original state of any worn out tangible asset which increases the duration time of the given asset, improves its capacity or restores its original mechanical state (MAKNICS ET AL., 2013). It is a characteristic of investment decisions that they bring about a change in either the financial background of an enterprise, or in the sources or in both. We consider an investment good if it has a positive net present value and the firm can realize an economical profit from the completion of the project (FENYVES, 2014). The indicator net present value is the difference between the net values of cash inflows and outflows. It takes both all of the cashflows expected in the future and their risk into consideration. If the net present value is more than zero, the investment counterbalances the expected payback requirement better than necessary, so the project has to be accepted. If the net present value is less than zero, the project has to be rejected, since the investment does not reach the required payback. If the net present value is zero, the payback is the same as the cost of capital, it does not generate changes in the shareholders' wealth, so it is indifferent whether to accept or refuse it (BÉLYÁCZ, 2007). The internal interest rate is a discount rate which makes the present values of all cashflows expected in the future equal to zero, meaning that the net present value is zero. In case of projects independent from each other, if the internal interest rate is more than the cost of capital, the project has to be accepted since it augments the shareholders' wealth. If the value of the internal interest rate is less than the cost of capital, the investment has to be rejected, it reduces the shareholders' wealth. However, if the indicator value is equal to the cost of capital, the decisionmaker may be indifferent regarding the acceptance or the rejection of the project, as the investment is not expected to change the shareholders' wealth. In case of projects mutually excluding each other on the basis of the internal interest rate we can have a different result than by means of the net present value, the reason of which is the reinvestment propisition (FENYVES ET AL., 2014). The discounted payback time integrates the advantages of both payback time and dynamic indicators. It indicates the measure of risks and liquidity. The indicator expresses how many years are necessary for the investment 
that the initially invested capital can show a return. When calculating it, we try to find that point in time when the amount of accumulated cashflows reaches the value of the initial capital investment (YESCOMBE, 2008). The profitability index shows the amount of the expected profit after the invested sources. If its value is more than one, the investment augments the shareholders' wealth, so the project can be accepted. If its value is less than one, the project has to be rejected, since less than a unit of the present value of the investment payback comes to a unit of investment (ILLÉS, 2009).

\section{RESULTS}

We employed the above mentioned economical indicators in proving all of our three presumptions, on the basis of which we were capable to decide whether the investment shows a return or not in the given way. Before starting the calculations, by means of the firm revenues and expenditures, and other budget data we defined the cashflows generated during the examined period of time and then we could start the economical calculations. We are presenting our results in the following table (Table 1).

Table 1. The results of our calculations

\begin{tabular}{|c|c|c|c|}
\hline Name & Case ${ } A "$ & Case , B" & Case ${ }_{9} C^{\prime \prime}$ \\
\hline $\begin{array}{l}\text { Net present value } \\
\text { (NPV) }\end{array}$ & $\begin{array}{c}\mathrm{NPV}=71,200,000 \mathrm{HUF} \\
(228,124.7 \mathrm{EUR})\end{array}$ & $\begin{array}{c}\mathrm{NPV}=-4,700,000 \mathrm{HUF} \\
(-15,058.8 \text { EUR })\end{array}$ & $\begin{array}{c}\mathrm{NPV}=150,300,000 \text { HUF } \\
(481,560.9 \text { EUR })\end{array}$ \\
\hline $\begin{array}{l}\text { Internal rate of return } \\
\text { (IRR) }\end{array}$ & $\mathrm{IRR}=11.2 \%$ & $\mathrm{IRR}=10.4 \%$ & $\mathrm{IRR}=13.5 \%$ \\
\hline Payback time (PB) & $\mathrm{PB}=5 \mathrm{yrs}$ & $\mathrm{PB}=6 \mathrm{yrs}$ & $\mathrm{PB}=5 \mathrm{yrs}$ \\
\hline $\begin{array}{c}\text { Discounted payback } \\
\text { time (DPB) }\end{array}$ & $\mathrm{DPB}=9-10 \mathrm{yrs}$ & $\mathrm{DPB}=10-11 \mathrm{yrs}$ & $\mathrm{DPB}=8-9$ yrs \\
\hline $\begin{array}{l}\text { Profitability index } \\
\text { (PI) }\end{array}$ & $\mathrm{PI}=1.1 \mathrm{HUF}$ & $\mathrm{PI}=0.9 \mathrm{HUF}$ & $\mathrm{PI}=1.2 \mathrm{HUF}$ \\
\hline
\end{tabular}

Source: our own data

In $\boldsymbol{C a s e}, \boldsymbol{A}$ ” (Hypothesis 1) we presumed that the investment will be financially recovered within the examined period of 10 years if it is financed from the firm's own source, the state grant and the bank credit. The net present value resulted 71,200,000 HUF $(228,124.7$ EUR), so it was more than zero, on the basis of which the investment is expected to increase the value of the enterprise and to result in a positive net income during the examined period. The value of the internal interest rate is $11.2 \%$ which is more than the profit of $8 \%$ expected by the investors, so the project can be accepted. The payback time is 5 years, so that time is necessary so that the investment can be recovered from the results given by the investment. Since it is less than the expected 10 years, this indicator also proves that the project can economically return. Calculating the discounted payback time, we got as a result that the present values of the future revenues reach the values of the present expenditures in 9-10 years, meaning that the investment returns in 9-10 years. According to the result of the profitability index, during the project more than 1 HUF, (1.1 HUF), of return can be expected after each 1 HUF of investment. So the investment is profitable in this case, too. The economical indicators calculated in Case "A" show positive results, so our Hypothesis 1 is reinforced, meaning that the investment can be recovered within 10 years if it is financed from the firm's own resource, state grant and credit.

In Case „B” (Hypothesis 2) we assessed the investment without the state grant and its return. In this case, the results differed from what we had presumed. The net present value 
showed a negative value: - 4,700,000 HUF (- 15,058.8 EUR), so it can be concluded that the investment does not bring about a positive net income, it reduces the value of the enterprise within the examined period. In spite of the unfavorable result, we calculated the other indicators, too, in order to see if they have the same result. The internal interest rate showed a positive value of $10.4 \%$, which is more than what the investors expected $(8 \%)$. On the basis of the payback time, 6 years are necessary to turn the investment to make profit. It is less than the expected 10 years, so the project can be accepted. The results of the internal interest rate and the payback time conflict with the one of the net present value, since it shows that the investment will not bring about profit in the examined 10 years. One of the reasons is that the payback time does not take the time value of money into consideration, also does not measure the profitability of the project proposal, moreover, the internal interest rate often leads to a result contrary to the net present value. All in all, we can conclude that in case of investment decisions it is worth acting considering the results of more indicators. The discounted payback time, in this case, was out of the period of 10 years. The investment will return within 10-11 years, on the basis of the calculation. The result of the profitability index shows that in case of 1 HUF of invested capital we can get back $0.9 \mathrm{HUF}$, so less than $1 \mathrm{HUF}$, meaning that the project reduces the enteprise's value. To sum it up, our Hypothesis 2 cannot be confirmed, since, on the basis of the results of 3 indicators out of 5 , the investment is not economical and profitable, either, in the examined period of 10 years, thus we rejected this hypothesis.

In Case „C" (Hypothesis 3) we intended to prove that the investment can be recovered from the firm's own source and state grant, without bank credit, will be recovered within the period of time of 10 years. The net present value was $150,300,000$ HUF $(481,560.9$ EUR), so it was more than zero, which proves that the investment increases the firm's value within the examined 10 years resulting a positive net income. The value of the internal interest rate was $13.5 \%$ which is more than the $8 \%$ expected by the investors, so the investment can be accepted. On the basis of the payback time, the project turned to be profitable after 5 years, so this indicator also proves that the investment is acceptable. On the basis of the discounted payback time, the present value of the future revenues reaches the value of the present expenditures, the 603,000,000 HUF, within 8-9 years. According to the profitability index, the investment brings about profit, since we can get back 1.2 HUF after each invested 1 HUF. All in all, the total results prove our Hypothesis 3, so the investment will be recovered in 10 years from the firm's own resource and state grant, without bank credit.

\section{CONCLUSIONS}

As a result, it can be concluded that two of our three hypotheses were reinforced, while one had to be rejected.

On the basis of our results, the investment will be economically recovered in 10 years being financed from the firm's own resource, state grant and credit (Case „A”, Hypothesis 1). This statement is supported by the positive net present value, the favorable internal interest rate, according to which the investment profit is better than it was expected by the investors. Also, the results of the payback time and the discounted payback time and the profitability index show that the investment is profitable in the examined period of 10 years.

The completion of the project can be successful without a bank credit, too, only from own resources and state grant (Case „C”, Hypothesis 3) and will be economically recovered. On the basis of the results the financing method of the Case „C" is the most welcoming for the 
firm, since the net present value is the highest in this case which increases the value of the enterprise, the value of the internal interest rate is the most positive, so the investment can bring about the largest profit here. Also, on the basis of the profitability index, it is the Case "C" which makes the most profit. Besides, the values of the payback time and the discounted payback time are the lowest in this case, so the fastest payback can be expected in Case „C".

However, the investment will not economically recovered within the examined period of 10 years if it is financed only from the firm's own resources and bank credit, which was assessed in Case „B”, Hypothesis 2. It is proved by the negative net present value, the unfavorable profitability index, according to which the investment is in the red in the examined period of 10 years. In addition, the value of the discounted payback time reflects, too, that the investment will not be returned in 10 years.

\section{ACKNOWLEDGEMENTS}

This research has been supported by the Ministry of Human Capacities, Human Capacities Grant Management Office and the National Talent Program (Proj. No NTP-HHTDK-0170004).

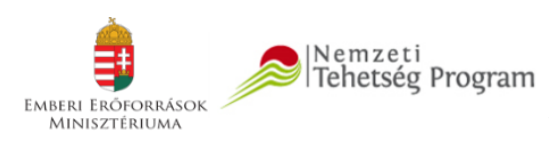

\section{EMBERI ERÖFORRÁS}

TÁMOGATÁSKEZELŐ

\section{REFERENCES}

BABINSZKY, L. ET AL. (2000): Állattenyésztés 3. - Sertés, nyúl, prémes állatok, hal. Mezőgazda Kiadó, Budapest. 329 p.

BALOGH, P, NÁBRÁd, A, POPP, J, SzÜCS, I. (2013): A kocatartás és a malacnevelés világés nemzetgazdasági jelentősége, helyzete. In: Balogh P., Novotniné Dankó G. (szerk.) (2013): Versenyképes kocatartás és malacnevelés. 282 p. Budapest: Szaktudás Kiadó Zrt., pp. 11-20.

BÉlYÁCZ, I. (2007): A vállalati pénzügyek alapjai. Aula Kiadó, Budapest. 383 p.

BRABANT, R. ET AL. (2012): Sertéstartás. Szaktudás Kiadó Ház Zrt., Budapest.

FABUlYA, Z., HAMPEL, GY., JoÓNÉ MuHI, P., KISS, M. (2015): Higher product safety in the production of canned food with software development, Analele Universitatii Din Oradea Fascicula Ecotoxicologie Zootehnie Technologii De Industrie Alinetara 14:(B): 149-156.

FEHÉR, A, SZAKÁLY, Z. (2017): Húsipari marketing. In: SZAKÁLY Z. (szerk.) Élelmiszermarketing. 518 p. Budapest: Akadémiai Kiadó, 2017. pp. 440-447.

FENYVES, V., TARNÓCZI, T., VÖRÖS, P. (2014): Financial indicators in managerial decisionmaking, Annals of the University of Oradea Economic Science 23(1): 893-904.

FENYVES, V. (2014): Pénzügyi mutatók szerepe a vezetői döntéshozatalban. Controller Info 2(3): 49.

GÁL, J. (2008): Food safety and quality in logistics process in people's view: Az élelmiszerbiztonság és minőség a logisztikai folyamatban az emberek megítélése alapján, In: The 3rd International Scientific Conference, Safety and Quality of Raw Materials and Foodstuffs. Nitra, Szlovákia, 2008.01.31-2008.02.01. pp. 157-160.

Horváth, J., KomAREK, L. (2016): A világ mezőgazdaságának fejlődési tendenciái. Szegedi Tudományegyetem Mezőgazdasági Kar, Hódmezővásárhely. 270 p. 
ILLÉS, I. (2009): Vállalkozások pénzügyi alapjai. SALDO Pénzügyi Tanácsadó és Informatikai Zrt., Budapest. 238 p.

IRIMIE, S.I., GAL, J., DUMITRESCU, C.D. (2014): Analysis of a dynamic regional system for the operationalizing of the sustainable development concept. Procedia-Social and Behavioral Sciences 124: 331-338.

Köteles, D., Benk, Á., Olasz, I., Mikó, E. (2017): Current problems in the pig production. In: Dragomirescu, M., Pacala, N., Pet, I., Stef, L. (szerk.) (2017): International Scientific Symposium "Bioengineering of Animal Resources 2017": Book of Abstracts. 51 p. Temesvár, Románia, 2017.05.25-2017.05.26. Temesvár: Banat's University of Agricultural Sciences and Veterinary Medicine, p. 31.

MAKNICS, Z., KARÁCSONY, Z., KoCsis, I., BANK, Cs. (2013): Mezőgazdasági alapismeretek. Nemzeti Agrárszaktanácsadási, Képzési és Vidékfejlesztési Intézet, Budapest. 388 p.

NovotninÉ DANKÓ, G. (2015): Sertéstenyésztés: a sertéstenyésztés, sertéstartás világ- és nemzetgazdasági jelentősége. Szaktudás Kiadó Ház Zrt., Budapest.

Popp, J., BALOGH, P., NÁBRÁDI, A., SzÜCS, I. (2013): A sertéshizlalás világ és nemzetgazdasági jelentősége. In: Balogh, P., Novotniné Dankó, G. (szerk.) (2013): Versenyképes sertéshizlalás. 240 p. Budapest: Szaktudás Kiadó Ház, pp. 11-32.

Yescombe, E.R. (2008): A projektfinanszírozás alapjai. Panem Kft., Budapest. 352 p. 